\title{
RESIDENTIAL MOBILITY DI PINGGIRAN \\ KOTA SEMARANG JAWA TENGAH \\ (Studi Kasus Kaum Miskin Kota di Kota Semarang)
}

\author{
Moh. Gamal Rindarjono \\ Program Studi Pendidikan Geografi, Jurusan PIPS, FKIP-UNS \\ Jl. Ir. Sutami 36 A - Surakarta, Telp/Fax: (0271) 648939; \\ E-mail:masGamal@yahoo.com
}

\begin{abstract}
श्厂 and quantitative methods, this research was applying distant-interpretation data in examining slum residentialphenomenon and terrestrial data in analyzing both social and cultural issues related to development of slum residential. This research resulting a residential mobility model throughout areas of research, especially sub-urban including the Chinese cemetery area; the new migrant was the urbanist namely the bridge headers group, consists of tramp and hobos whom should be concerned more. Though they just have settled in short-period within the area, their income was categorized financially settled. They owned their own home not as the renter and even, built housing for their subordinates amounted 7-15 families in a complex of residential. Stability of the income was also supported by resident-owning whereas selecting its location based on the land-availability which initially settled the location illegally among the graves. This location was selected since its less-maintained condition by neither their descendant nor cemetery officer which then densely covered by bushes. Availability of the sufficient land leads them to build their residential which also used as the scrap collection space. During the times, their number was increased referred to their raising income. Legalizing their residential was the next step for their existence and sustainability by purchasing or renting the land. Eventually this bridge header was earning a stable income, owning their own home, and locating their residential in the sub-urban area furthermore but unfortunately less-supported by a highly established life style but an early category one. These were indicated by several factors, either employer or subordinate tramps which cooking foods altogether, unfashionably worn, and behavior of their youngster of asking consideration and advice to the consolidator and status seeker.
\end{abstract}

Key words: mobility, residential, slum area.

\section{PENDAHULUAN}

Menurut proyeksi World Population Data Sheet (2002) penduduk Indonesia pada tahun 2025 akan berkisar 281,9 juta jiwa dengan Crude Birth Rate sebesar 2,2\%, Crude Death Rate sebesar 0,6\% dan Crude Growth Rate sebesar 1,6\%. Berdasarkan hasil sensus penduduk 2000, jumlah penduduk Indonesia pada tahun 2005 meningkat dua kali lipat dari tahun 1985, hal ini dapat dimungkinkan mengingat pertumbuhan penduduk di Indonesia yang masih relatif tinggi yakni 1,35\%. Dengan demikian estimasi World Population Data Sheet serta hasil Sensus Penduduk Tahun 2000 menjadikan Indonesia sebagai negara dengan tingkat pertumbuhan sangat cepat (1,5\%-2\% per tahun), sehingga keduanya mengingatkan adanya tingkat pertumbuhan yang masih tinggi dan 
perlu mendapat perhatian yang serius dalam penanganannya. Peningkatan jumlah penduduk yang tinggi ini akan berdampak pada aspek kehidupan yang luas, diantaranya adalah tuntutan kebutuhan dasar manusia akan pangan dan papan. Tuntutan kebutuhan da-sar tersebut tidak lepas dari ketersediaan akan lahan, lahan baik di perdesaan maupun lahan di perkotaan.

Peningkatan kebutuhan akan lahan, khususnya di daerah perkotaan semakin nampak terutama lahan sebagai wadah untuk menampung kegiatan manusia maupun sebagai wadah untuk bermukim. Pesatnya perkembangan kota menjadi salah satu daya tarik bagi penduduk di daerah hinterland, untuk berbondong-bondong bermigrasi masuk ke daerah perkotaan, hal ini akan berakibat terkonsentrasinya penduduk di sekitar zona inti kota (core zone) atau di zone selaput inti kota, seiring dengan pertumbuhan penduduk yang disebabkan oleh faktor alamiah maupun adanya migarasi penduduk ke daerah perkotaan, permintaan akan lahan untuk permukiman juga semakin meningkat, sementara luas lahan kota secara administratif tetap, konsekuensi ekonomis yang harus disandang adalah harga akan lahan semakin meningkat, akibat yang muncul terutama bagi migran dan juga penduduk kota yang status ekonominya lemah, adalah rendahnya kemampuan untuk memiliki rumah.

Dampak yang terjadi selanjutnya adalah terjadinya pemadatan bangunan (densifikasi) permukiman, yang berakibat menurunnya kualitas permukiman, dengan demikian di daerah perkotaan akan timbul daerah-daerah permukiman yang kurang layak huni yang sangat padat, dan hal ini akan membawa suatu akibat pada kondisi lingkungan permukiman yang buruk, yang selanjutnya disebut sebagai daerah kumuh (slum area).

Menurut catatan PBB tahun 2004, sekitar 1 (satu) milyar masyarakat di seluruh dunia hidup di permukiman kumuh (bttp//:www.City withouth slum.com). Jumlah penduduk yang tinggal di permukiman kumuh di seluruh dunia ini meningkat 36 $\%$ dalam dasawarsa 90an, dalam 3 dasawarsa yang akan datang diperkirakan penduduk yang tinggal di permukiman kumuh mencapai 2 milyar jiwa. Kota - kota di Afrika 40 - 70 persen penduduknya tinggal di permukiman kumuh, sebagai contohnya adalah di Nairobi $60 \%$ penduduknya tinggal di permukiman kumuh (bttp//:wmw.UN-HABITAT.Com).

Di Indonesia permukiman kumuh hingga tahun 2000 mencapai luasan 47 ribu hektar. Di kota-kota besar pada tahun 2002 meliputi: Jakarta dengan luasan 4.481,6 hektar dan dihuni oleh 2,4 juta jiwa atau sekitar $20 \%$ dari seluruh penduduknya 4,296 dari luas permukiman keseluruhan, Bandung meliputi 402 hektar dihuni oleh 205.465 jiwa atau $20 \%$, Surabaya meliputi luasan 2.196 hektar dihuni oleh 900.870 jiwa (25\%).(http:\www.Kimpraswil.go.id/ humas/ infoterkini/ppw 091002.htm).

Penelitian ini bertujuan untuk mengkaji perkembangan permukiman kumuh di Kota Semarang dari tahun 1985-2005, kajian penelitian ini meliputi kajian penyebab perkembangan permukiman kumuh karena faktor ekonomi dan faktor geografi yang berkaitan dengan penemuan fenomena baru yang tidak sejalan dengan teori yang dikemukakan oleh Turner (1968).

Salah satu penyebab munculnya permukiman kumuh adalah adanya 
urbanisasi yang tidak terkendali, proses pengkotaan (urbanisasi) baik secara fisik maupun karena adanya mobilitas penduduk dari luar perkotaan berakibat terhadap adanya krisis perumahan (DrakakisSmith,1980). Peningkatan kebutuhan akan lahan untuk bertempat tinggal bagi penduduk kota yang tidak diimbangi dengan peningkatan luas lahan akan menyebabkan terjadinya pemadatan rumah mukim (densifikasi) dan menurunnya kualitas permukiman itu sendiri (deteriorisasi), dua hal tersebut merupakan faktor yang menyebabkan proses taudifikasi berjalan terus menerus. Masuknya penduduk dengan berbagai aktifitasnya dari daerah hinterland kota ke daerah perkotaan, ternyata tidak diimbangi dengan sikap serta kultur kota, hal ini tercermin dari ketidaksiapan para migran yang datang kekota, baik dari segi ketrampilan, pendidikan, maupun mental kultural.

Ketidaksiapan tinggal di tempat yang baru dengan berbagai bentuk budaya yang baru, mengakibatkan para pendatang di perkotaan ini menjadi tidak produktif. Kebiasaan-kebiasaan rutin di daerah asalnya ternyata sangatlah berbeda dengan yang dijumpainya saat ini, kesilitan mencari pekerjaan adalah hal yang sangat lumrah ditemui oleh para pendatang, pendapatan yang sangat rendah adalah hal yang sangat logis sebagai imbalan yang didapatnya karena pekerjaan yang tanpa keahlian. Kehidupan yang miskin adalah merupakan refleksi dari kenyataan kehidupan kebanyakan para pendatang, yang selanjutnya disebut sebagai masyarakat miskin kota.

Secara teoritis ada dua pendapat yang mengemukakan tentang masyarakat miskin kota dalam hal tingkat ekonominya, pendapat yang pertama menyatakan bahwa kaum miskin kota akan dengan sendirinya terangkat jika pembangunan ekonomi negara sudah mapan,sedangkan pendapat yang lain menyatakan bahwa tidak percaya masyarakat miskin kota dapat keluar dari kemiskinannya jika cara-cara produksi kapitalis masih tetap berfungsi. Untuk pendapata yang pertama, Nelson (1979) dalam penelitiannya menunjukkan beberapa contoh tentang adanya mobilitas sosioekonomi diantara penduduk miskin di kota-kota Sao Paulo, Buenos Aires, dan Poona, di ketiga kota yang diteliti tersebut, didapati bahwa kebanyakan dari anak-anak yang orangtuanya tidak mempunyai ketrampilan (unskilled) saat dewasa telah dapat keluar dari jenis pekerjaan tanpa ketrampilan. Di Buenos Aires, hanya $21 \%$ dari anak-anak pekerja tanpa ketrampilan tetap tiddak punya ketrampilan, di Sao Paulo $31 \%$ dan di Poona $43 \%$. Sedangkan sisanya dari ketiga koa tersebut menjadi tenaga terampil, sebagian bahkan bekerja sebagai tenaga kantoran, dan diantaranya bahkan menduduki jabatan administratif atau profesional yang tinggi.

Pendapat yang kedua dikuatkan dari hasil penelitian Perlman (!976), angket yang yang dibuatnya untuk para pekerja laki-laki di tiga buah di daerah permukiman liar di Rio de Janeiro, menunjukkan kemerosotan taraf hidup mereka dibandingkan orang tua mereka. Perlman mengumpulkan riwayat hidup 269 lelaki yang memiliki dua atau lebih jenis pekerjaan di Rio de Janeiro dan mengelompokkan semua jenis pekerjaan sebagai pekerjaan yang tanpa ketrampilan, dengan ketrampilan sedang dan berketrampilan tinggi. Kemudian ditelitinya perubahan-perubahan pekerjaan yang terjadi, apakah pekerjaan yang baru memerlukan ketrampilan yang lebih tinggi, lebih rendah atau sama dengan pekerjaan sebelumnya. 
Lebih dari setengah perubahan pekerjaan yang terjadi tidak mengalami perubahan tingkat ketrampilan.

\section{METODE PENELITIAN}

Penelitian ini berlokasi di kota Semarang yang ditentukan berdasarkan purposive, pertimbangan utama kota Semarang sebagai daerah penelitian adalah : (1) Daerah penelitian telah ditentukan dengan berdasarkan pada tujuan penelitian yang akan mengkaji penyebab berkembangnya permukiman kumuh, penyebab dari perkembangnya permukiman kumuh ini dilihat dari faktor penyebab ekonomis, geografis (2) Adanya variasi keruangan di dalam struktur intern kota Semarang yakni adanya perbukitan di daerah peri-peri, daerah dataran rendah di daerah selaput kota dan inti kota serta daerah costal (pantai) di pinggiran sebelah utara yang tentu saja akan sangat berbeda fenomenanya dikaji dari factor penyebab, berkembangnya permukiman kumuh, hal ini yang sesuai dengan pendekatan keruangan dalam studi Geografi yang akan dipergunakannya.

Populasi dalam penelitian ini adalah seluruh daerah permukiman kumuh yang ada di Kota Semarang yang luasnya meliputi $876 \mathrm{Ha}$ dan tersebar di berbagai pelosok Sampel penelitian diambil pada daerah inti kota, selaput inti kota dan daerah pinggiran kota, penentuan daerah sampel ini berdasarkan pembagian zone kota- Desa oleh Bintarto (1989).

Daerah sample penelitian meliputi Kelurahan Mrican yang berada di Pusat kota, Kelurahan Pekunden yang berada di selaput inti kota, Kelurahan Karangrejo Kecamatan Gajahmungkur yang berada di Jatingaleh dan mewakili daerah pinggir kota yang berada di perbukitan, Kelurahan
Tandang Kecamatan Tembalang yang berada di Kuburan Cina juga sekaligus mewakili daerah pinggiran kota di dataran rendah, serta Kelurahan Bandarharjo sebagai gambaran untuk wilayah pinggiran kota yang berada di pantai, jumlah responden adalah sebanyak 250 kepala keluarga.

\section{HASIL DAN PEMBAHASAN}

\section{Faktor Ekonomi}

Menurut Turner (1971) yang merujuk pada teori tentang kebutuhan dasar manusia dari Maslow, terdapat kaitan antara kondisi ekonomi seseorang dengan skala prioritas kebutuhan hidup dan prioritas kebutuhan perumahan, prioritas tersebut di gambarkan sebagai berikut: (Sumber: Turner (1972))

Dari gambar tersebut di atas, dapat dijelaskan bahwa dalam menentukan prioritas tentang rumah, seseorang atau sebuah keluarga yang berpendapatan sangat rendah cenderung meletakkan prioritas utama pada lokasi rumah yang berdekatan dengan tempat yang dapat memberikan kesempatan kerja. Tanpa kesempatan kerja yang dapat menopang kebutuhan seharihari, sulit bagi mereka untuk dapat mempertahankan hidupnya. Status kepemilikan rumah dan lahan menempati priorotas kedua, sedangkan bentuk maupun kualaitas rumah adalah merupakan priorotas terakhir, yang terpenting pada tahap ini adalah tersedianya rumah untuk berlindung dan beristirahat dalam upaya mempertahankan hidupnya.

Dari hal di atas dapat disimpulkan bahwa, bagi masyarakat berpenghasilan rendah dan sangat rendah, faktor jarak antara lokasi rumah dengan tempat kerja menempati prioritas utama. Faktor keje- 


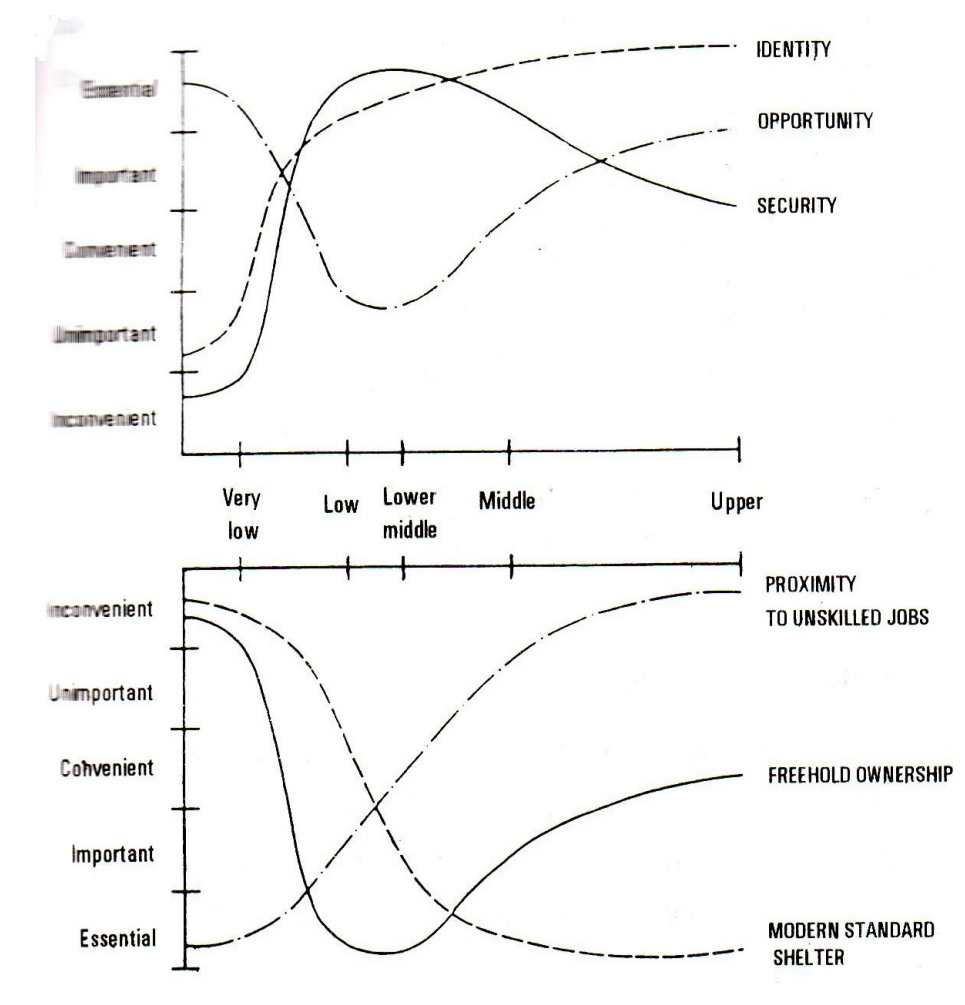

Gambar 1. Kaitan Antar Prioritas Kebutuhan Hidup dan Perumahan dengan Penghasilan

lasan status kepemilikan lahan dan rumah menjadi prioritas kedua, sedangkan bentuk dan kualitas bangunan tetap menempati prioritas yang paling rendah.

Hasil penelitian memperlihatkan fenomena yang cukup menarik, khususnya kaitan antara prioritas lokasi tempat tinggal dengan jarak sumber mata pencaharian (proksimitas), untuk melihat fenomena tersebut disajikan dalam tabel berikut ini

Tabel di atas memperlihatkan alasan dalam memilih tempat tinggal, alasan utama berdasarkan teori Turner (1972) yakni bagi masyarakat berpenghasilan rendah dan sangat rendah, faktor jarak antara lokasi rumah dengan tempat kerja menempati prioritas utama, ternyata hanya berlaku pada daerah penelitian yang letaknya di daerah yang dekat pusat kegiatan dalam hal ini adalah mereka yang tinggal di Kelurahan Pekunden. Alasan utama mereka yang menjadikan proksimitas sebagai alasan utama adalah karena mereka sebagian besar (41,5\%) penduduknya bermata pencaharian sebagai pedagang keliling, daerah tempat jualan tidak terlalu jauh dari tempat tinggal mereka yakni di sekitar mal-mal, serta di tepian atau perempatan jalan yang dekat dengan simpang lima. Sedangkan sisanya adalah mereka yang bekerja seagai buruh pabrik, pekerja yang bergerak di bidang jasa, mulai dari sales, satpam, sopir, teknisi, tukang becak, dan tukang angkut barang.

Di Kelurahan Karangrejo Kecamatan Gajahmungkur yang terletak di derah Jatingaleh, keadaan permukiman kumuh di daerah ini paling banyak adalah rumah sederhana, yakni rumah dengan tiang dari kayu, sedangkan hampir sebagian besar 
Tabel 1: Kaitan Antara Prioritas Letak Tempat Tinggal dengan Proksimitas, Murahnya Harga lahan, kedekatan dengan Saudara dan Faktor Psikologis

partisinya terbuat dari gedek bambu dengan lantai masih dari tanah yang diratakan, rumah dengan kategori sementara ini mencapai $52 \%$. Didalam penelitian ditemukan bahwa keberadaan rumah sementara yang demikian banyak ini, disebabkan karena adanya social capital yang cukup besar di dalam masyarakat. Penduduk yang bertempat tinggal di daerah tersebut dan pada saat akan mendirikan rumah tinggal, maka para tetangga akan membantu dalam bentuk tenaga serta materi, materi dalam hal ini adalah membantu penyediaan bambu.

\section{Faktor Geografi}

Faktor geografi dalam hal ini adalah meliputi letak dan ketersediaan lahan, lahan di perkotaan khususnya untuk perumahan semakin sulit didapat dan semakin mahal, hal ini tentu saja di luar keterjangkaun sebagian besar anggota masyarakat, sulitnya akses untuk memperoleh lahan bagi masyarakat berpenghasilan rendah antara lain disebabkan oleh spekulasi lahan, kepemilikan lahan yang berlebihan oleh pihak-pihak tertentu, aspek hukum kepemilikan, dan ketidak jelasan kebijaksanaan pemerintah dalam masalah lahan (Abrams; 1969).
Hal inilah yang menjadi pemicu munculnya kantong-kantong permukiman kumuh di kota-kota besar, munculnya permukiman kumuh di kota-kota besar khususnya di Indonesia tidak terlepas dari fenomena mobilitas penduduk yang ditengerai adanya gerakan sentry fugal dan sentry petal. Gerakan sentripetal dan sentrifugal ini mengacu pada toeri kekuatan dinamis (dinamyc forces theory) yang dikemukakan oleh Colby (1933).

Dalam penelitian ini ditemukan prosentase terbesar kekuatan gerakan sentripetal terdapat di daerah pinggiran, yakni di daerah Kuburan Cina dengan kekuatan utama adalah ketersediaan lahan, namun tidak dapat dipungkiri pula bahwa kelekatan daerah pinggiran kota ini dengan daerah kekotaan adalah suatu yang tidak dapat dipungkiri, walaupun daerah pinggiran kota masih ditandai oleh sifat kedesaan, namun sejalan dengan perjalanan waktu, peningkatan jumlah penduduk, peningkatan fungsi kekotaan dan pembangunan prasarana kegiatan kekotaan yang ada, tidak pelak lagi bahwa daerah pinggiran kota menjadi sasaran terdekat bagi pemekaran kota dan hal ini menjadi pemicu dan 
Tabel 3: Kekuatan - kekuatan Penarik Gerakan Sentripetal

\begin{tabular}{|l|c|c|c|c|}
\hline Wilayah & $\begin{array}{c}\text { Berdasarkan } \\
\text { Proksimitas } \\
\mathbf{( \% )}\end{array}$ & $\begin{array}{c}\text { Ketersediaan } \\
\text { Lahan (\%) }\end{array}$ & $\begin{array}{c}\text { Kedekatan } \\
\text { dg Kerabat } \\
\mathbf{( \% )}\end{array}$ & $\begin{array}{c}\text { Ketersediaan } \\
\text { Fasilitas } \\
\mathbf{( \% )}\end{array}$ \\
\hline Pekunden & 46 & 2 & 14 & 38 \\
\hline Mrican & 38 & 32 & 6 & 16 \\
\hline Jatingaleh & 6 & 22 & 20 & 52 \\
\hline Kuburan Cina & 18 & 62 & 10 & 2 \\
\hline Bandarharjo & 22 & 10 & 36 & 26 \\
\hline
\end{tabular}

Sumber: analisis data primer

pemacu proses urbanisasi sentrifugal, yang dalam pengertian morfologi kekotaan termanifestasikan dalam proses urban sprawl.

Pergerakan penduduk dengan segala aktivitasnya menuju daerah pinggiran kota di kuburan cina ini mengakibatkan adanya suatu perubahan persepsi tentang mobilitas tempat tinggal atau yang oleh Turner (1968) disebut sebagai Residential Mobility, di dalam mobilitas tempat tinggal ini ada empat dimensi yang saling berkaitan yakni: tingkat pendapatan (income), gaya hidup (life cycle), kepemilikan rumah (housing) dan lokasi tempat tinggal (location), dimensi tersebut berkaitan dengan lama mereka (urbanit) bertempat tinggal di kota.

Di dalam Residential Mobility Theory, Turner beranggapan bahwa keluarga-keluarga urbanit dengan penghasilan yang sama, serta memiliki siklus kehidupan yang sama akan memiliki tiga pemikiran yang sama seperti di atas. Para pendatang baru disebut sebagai bridgeheaders akan menomorsatukan derajat keterjangkaun yang tinggi terhadap tempat kerjanya di kota, sedangkan kenyamanan dan keamanan tempat tinggal adalah sesuatu yang agak dikesampingkan. Kelompok bridgeheaders ini akan bertempat tinggal di puasat kota dengan cara menyewa petak-petak rumah bersama-sama dengan teman kelompoknya. Seiring dengan perjalanan waktu bridge-headers ini lama kelamaan terjadi peningkatan ekonomi sejalan dengan kemantapan mereka bekerja, sehingga terjadi perubahan pemikiran tentang kebutuhan tempat tinggal, pada saat sebelumnya mereka lebih mementingkan kedekatan dengan tempat bekerja dan menempati permukiman yang kurang memadahi, namun kemudian mereka tidak lagi menekankan kedekatan tempat tinggalnya dengan tempat kerja sebagai acuan prioritas utama dalam kehidupannya. Berdasarkan teori mobilitas tempat tinggal (residential mobility theory) dari Turner (1968) kelompok bridgeheaders yang berubah pola pikirnya ini disebut sebagai consolidatros.

Turner menjelaskan dalam teorinya tersebut, bahwa empat dimensi mobilitas yankni pendapatan (income), gaya hidup (life cycle), tempat tinggal (housing) dan pemilihan lokasi (location) saling berhubunguan satu sama lain, serta semua keluarga yang termasuk dalam karakteristik yang sama diasumsikan mempunyai persepsi yang sama terhadap parameter pemilihan tempat tinggal. 
Berdasarkan hasil penelitian ditemukan model Residential mobility (mobilitas tempat tinggal) di daerah penelitian khususnya di daerah pinggiran yakni di daerah kuburan cina sebagai berikut, para pendatang adalah para urbanit yang belum lama tinggal di daerah tersebut sehingga dalam istilah Residential Mobility disebut sebagai kelompok bridgeheaders. Kelompok ini kebanyakan adalah para pemulung dan pengepul (lapak), kehidupan para lapak perlu di diskusikan di dalam hal ini. Para lapak adalah termasuk kelompok bridgeheaders yang belum lama tinggal di kota, namun para lapak di dalam kelompoknya merupakan golongan dengan pendapatan yang relatif tinggi. Mereka juga telah memiliki tempat tinggal sendiri bukan lagi sebagai penyewa rumah, bahkan mereka membangunkan rumah untuk ditempati para "bawahannya" yakni para pemulung yang berjumlah 7 hingga 15 keluarga, dalam satu komplek.

Kestabilan pendapatan para lapak ini diikuti dengan kepemilikan tempat tinggal, sedangkan pemilihan lokasi tempat tinggal dipilihnya berdasarkan ketersediaan lahan, mereka pada awalnya menempati lahan secara illegal diantara kuburan. Seiring dengan perjalanan waktu para pemulung yang bergabung juga semakin banyak, maka pendapatan para lapak inipun juga semakin mantap. Langkah berikutnya adalah mereka mencoba melegalkan tempat tinggal mereka dengan cara membeli lahan yang sudah mereka tempati atau menyewa lahan tersebut kepada seseorang yang dianggap menguasai daerah tersebut.

Para lapak yang masuk kelompok bridgeheaders ini sudah memiliki pendapatan yang stabil walauapun belum lama tinggal di kota, mereka juga tidak lagi menjadi penyewa rumah tetapi telah memiliki tempat sendiri, demikian juga pemilihan lokasi tidak lagi berada di dalam kota, namun berada di pinggiran kota, kenyataan ini tidak diikuti olah gaya hidup (life cycle) yang mapan (bigh) namun gaya hidupnya masih tetap dalam kategori awal (early), hal ini dibuktikan dengan kebiasaan sehari-hari yang masih sangat sederhana, dan yang paling menonjol adalah para lapak yang masih tergolong muda ini masih selalu minta pertimbangan dan nasihat tentang berbagai hal kehidupan kepada orang-orang yang sudah lama tinggal di kota (cosolidators maupun status-seekers). Di dalam mobilitas tempat tinggal menurut Turner (1968) dan hasil temuan di daerah penelitian ini ditampilkan pada Gambar 2 dan Gambar 3.

\section{KESIMPULAN}

Dari uraian tersebut di atas, dapat disimpulkan bahwa di daerah penelitian khususnya di daerah pusat kota dan selaput inti kota tidak sesuai dengan apa yang dikemukakan oleh Turner (1968) atau ada suatu penyimpangan, hal ini sangatlah wajar sebab teori yang diungkapkan oleh Turner berkaitan erat dengan daerah penelitian yang dilakukan di negara maju, sedang hasil penelitian yang menyimpang atau kurang sesuai dengan teori yang diungkapkan oleh Turner, yakni:(1) Lokasi tempat tinggal bagi kaum miskin kota di daerah penelitian tidak tergantung pada proksimitas yaitu;(2) Untuk mendirikan rumah, kaum miskin kota tidak atau kurang memperhatikan status lahan. Status kepemilikan lahan dan rumah tidak harus legal bahkan illegal-pun tidak menjadi masalah, karena adanya jaminana rasa aman yang diberikan oleh seseorang atau kelompok tertentu dari penggusuran oleh pemerintah atau pemilik yang sah.(3) Rumah tinggal bagi kaum miskin kota tidak menjadi perhatian yang 


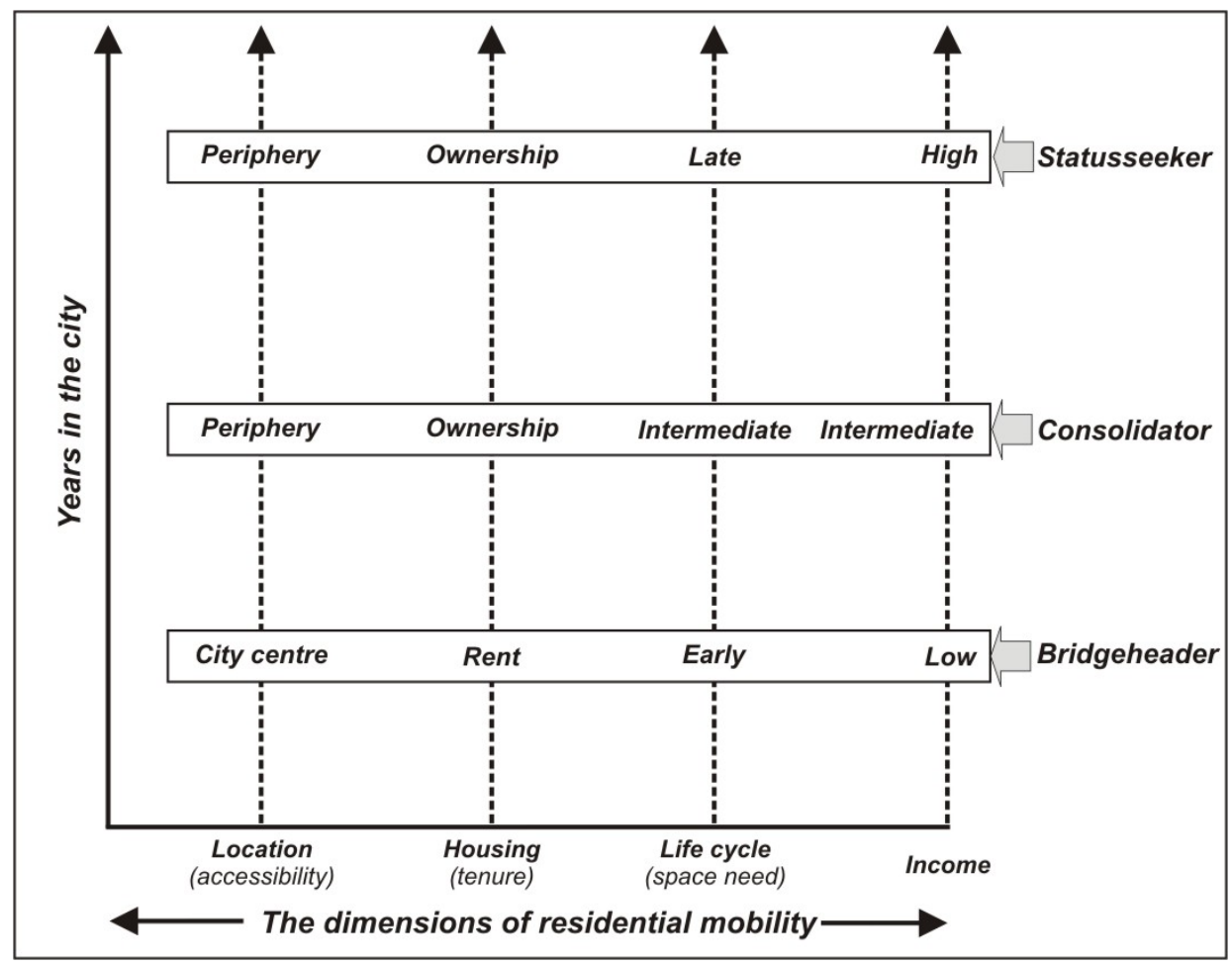

Gambar 2: Model Mobilitas Tempat Tinggal Oleh Turner (1968)

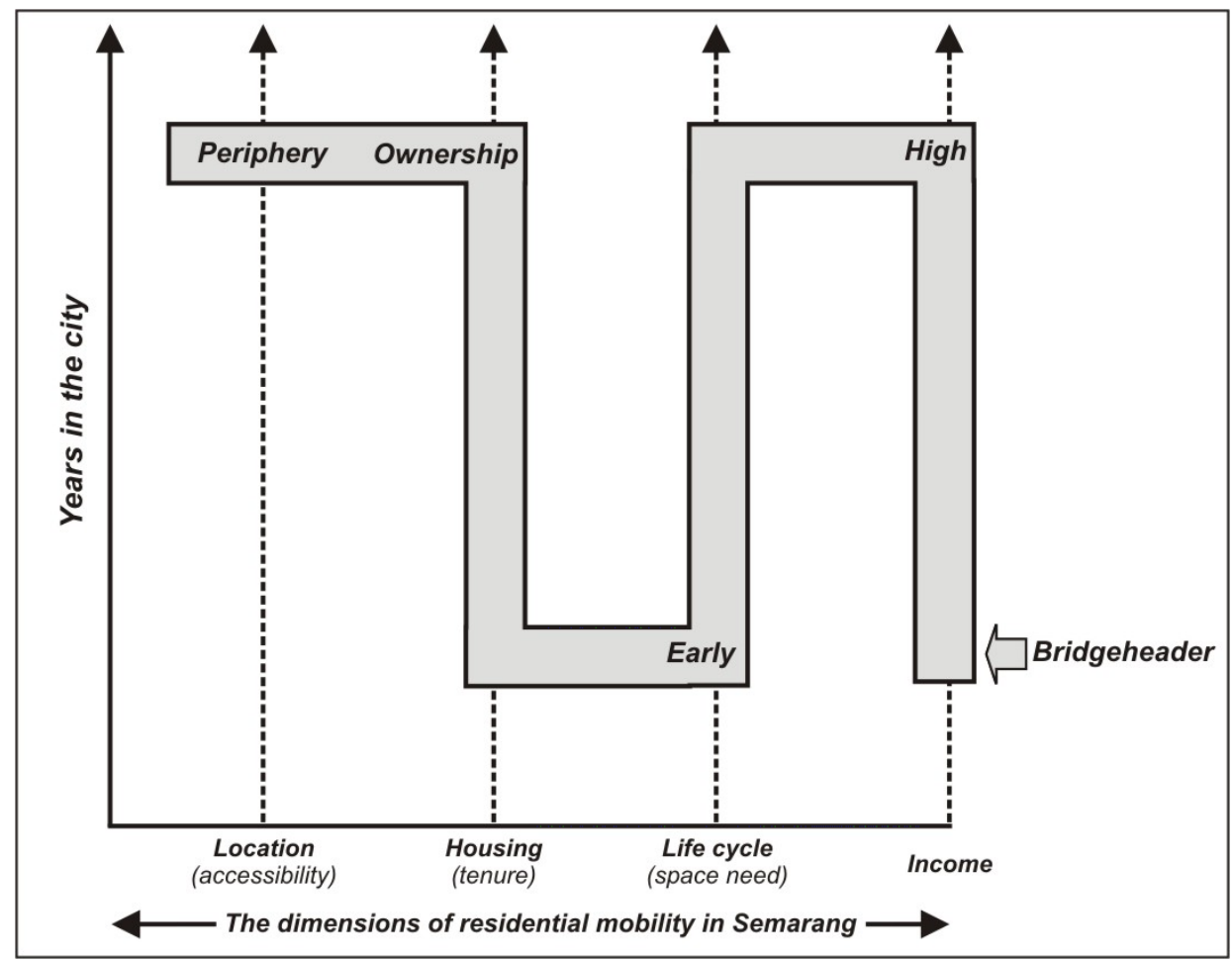

Gambar 3. Model Mobilitas Tempat Tinggal Hasil Penelitian 
mendasar. Bentuk dan kualitas bangunan tidak perlu terlalu baik, tetapi cukup untuk memenuhi fungsi dasar yang diperlukan penghuninya.(4) Harga atau biaya pembangunan rumah sering lebih besar dari tingkat pendapatan mereka, karena adanya social capital dari lingkungannya. (5) Bebe- rapa urbanit yang masuk dalam status bridge-header, justru memiliki penghasilan yang cukup tinggi, sudah mempunyai rumah sendiri, dan memilih tinggal di luarkota, namun gaya hidup mereka masih dalam gaya hidup awal, hal ini sangat berbeda dengan hasil penemuan Turner (1968).

\section{DAFTAR PUSTAKA}

Bintarto, R. (1989); Interaksi Desa Kota, Jakarta: Ghalia Indonesia

Brand, Richard R. (1976); The Urban Haousing Challenge. In: C. Ggregory Knight and James L.Newman (eds): Contemporary Africa: Geography and Change. New Jersey: Prentice-Hall Inc.

Colby,C.C., (1959); Centrifugal and Centripetal Forces in Urban Geography. In: Mayer and Kohn (eds): Reading in Urban Geography. Chicago: University Of Chicago.

Desai,A and Smita Sen Gupta, (1987); Problems of Changing of Land Use Pattern in the Urban Fringe: The Case of Abmedabad. In: C.S. Yadav (ed): Perspectives in Urban Geography: Rural-Urban Fringe. New Delhi: Concept Publishing Company.

Drakakis-Smith,David (1980); (terjemahan) Perencanaan Kota, Jakarta: Erlangga.

Drakakis-Smith, David (1980); Urbanisation, housing, and the Development Process, New York:ST. Martin's Press.

Edward, Michael (1983); Residential Mobility in a Changing Housing Market: The Case of Bucaramangga, Colombia, Journal Urban Studies, Vol 20:131-145 .

Harjanto. 2004. "Bahaya Perubahan Penggunaan Lahan di Kota Semarang". Forum Geografi, Vol. 18, No. 2, Desember 2004. Hlm 152-160.

http//:www.City withouth slum.com.

http//:www.UN-HABITAT.Com.

http//www.Kimpraswil.go.id/ humas/ infoterkini/ppw 091002.htm

Nelson Joan M. (1979); Access to Power Politics and Urban Poor in Developing Nations, New Jersey, Prinnceton University Press.

Perlman Janice E.(1976); The Myth of Marginility, Urban Poverty and Politics in Rio de Jeneiro, Berkley, University of California Press.

Russwurm,L.H.,(1977); Countrry Reridential Development and the Regional City Form in Canada. In; Ontario Geography 10.

Turner, J.F.C., (1968); Housing Priorities, Settlement Paterns, and Urban Devolopment in Modernising Countries, Journalof the American Institute Planners, Vol, 34:354-363. 
Turner, J.F.C., (1976); Housing By People, Towards Autonomy in Building Environment, London:Morions Boyars Publiser Ltd

Yunus, Hadi Sabari (2001); Perubahan Pemanfaatan Lahan Di Daerah Pinggir Kota Kasus di Pinggiran Kota Yogyakarta,Disertasi,Universitas Gadjah Mada, Yogyakarta. 


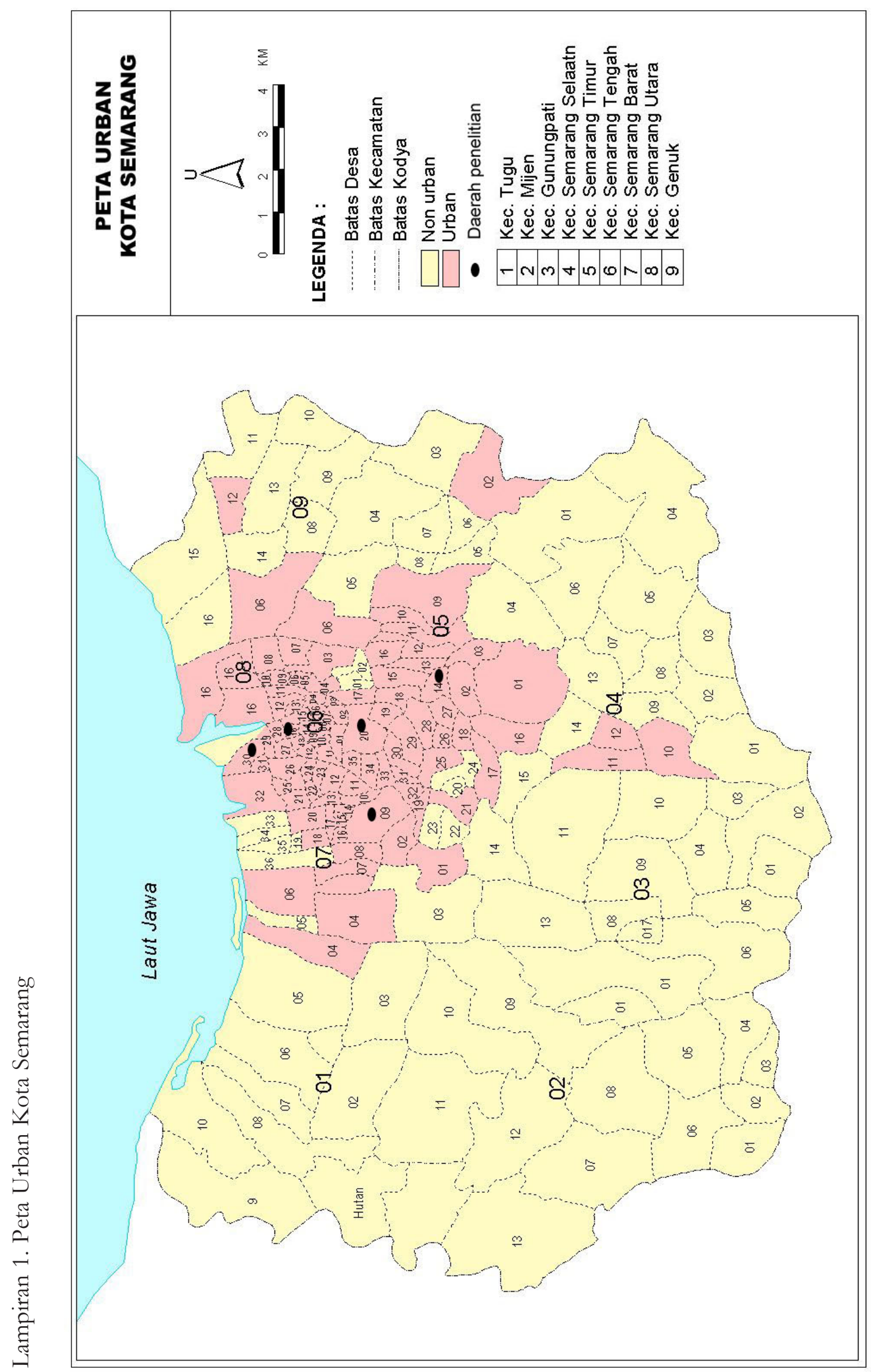

